\title{
Oxalate Oxidase Model Studies - Substrate Reactivity
}

\author{
Piotr L. Pawlak, ${ }^{[a]}$ Manashi Panda, ${ }^{[a]}$ Jia Li, ${ }^{[a]}$ Atanu Banerjee, ${ }^{\text {[a] }}$ \\ Derek J. Averill, ${ }^{\text {[a] }}$ Borislava Nikolovski, ${ }^{\text {[a] }}$ Brian J. Shay, ${ }^{\text {bb] }}$ \\ William W. Brennessel, ${ }^{[c]}$ and Ferman A. Chavez ${ }^{*[a]}$
}

Keywords: Enzyme models / Oxalate oxidase / Cyclic voltammetry / Manganese / EPR spectroscopy

The synthesis and structure of $[\mathrm{MnLCl}] 0.5 \mathrm{H}_{2} \mathrm{O}\left(\mathbf{1} \cdot 0.5 \mathrm{H}_{2} \mathrm{O}, \mathrm{HL}\right.$ = 1-benzyl-4-acetato-1,4,7-triazacyclononane) is reported. Complex 1 exists as a coordination polymer in the solid state, and the $\mathrm{Mn}^{\mathrm{II}}$ center is bonded to three amine nitrogen atoms, one carboxylate oxygen atom, a chlorido ligand, and an adjacent carboxylate group in a chelating fashion to afford a seven-coordinate center. The dissolution of $\mathbf{1}$ in acetonitrile containing excess oxalate (ox) ions results in a monomeric species. When mixtures of $\mathbf{1}$ and oxalate ions are exposed to oxygen under ambient conditions, a dark pink EPR-silent species is generated. The pink species is believed to be $\left[\mathrm{Mn}^{\mathrm{III}}(\mathrm{ox})_{2}\right]^{-}$, which results from the displacement of the ligand $\mathrm{L}^{-}$by an oxalate ion. The decomposition of this species ultimately results in the formation of 1 equiv. of $\mathrm{CO}_{2}$ per oxalate ion consumed, a $\mathrm{HCO}_{3}{ }^{-}$ion, and a $\mathrm{Mn}^{\mathrm{II}}$ species. Further reaction of the resulting $\mathrm{Mn}^{\mathrm{II}}$ species with excess oxalate in the presence of oxygen leads to additional oxalate degradation.

\section{Introduction}

Oxalate is produced by plants and microbes by the hydrolysis of oxaloacetate or by the oxidation of glyoxylate or ascorbate. ${ }^{[1]}$ Oxalate secreted by fungi promotes the degradation of lignin. ${ }^{[2]}$ The accumulation of oxalate in leafy plants such as spinach and Amaranthaceae leads to nutritional stress, as these plants lack the ability to catabolize oxalate. Excess oxalate in the diet of humans may lead to hyperoxaluria, which has been implicated in several pathological conditions such as the formation of calcium oxalate stones in the kidney (urolithiasis), renal failure, cardiomyopathy, and cardiac conductance disorders. ${ }^{[3]}$ Oxalate oxidase (OxOx), also known as germin, is expressed by plants such as wheat and barley and catalyzes the manganese-dependent oxidative decarboxylation of oxalate ions to carbon dioxide and hydrogen peroxide [Equation (1)] and protects plants from the toxic effects of oxalate. ${ }^{[4]}$

The structure of $\mathrm{OxOx}$ was solved at resolution of $1.6 \AA{ }^{[6]}$ Each OxOx monomer possesses the predicted jellyroll barrel that is characteristic of the cupin superfamily. ${ }^{[4]}$ A manganese ion is bound to the side chains of conserved glutamate and histidine residues in a site that is located toward the narrow end of the barrel-like domain.

[a] Department of Chemistry, Oakland University,

Rochester, MI 48309-4477, USA

E-mail: chavez@oakland.edu

https://files.oakland.edu/users/chavez/web/Research.htm

[b] Biomedical Mass Spectrometry Facility, University of Michigan,

Ann Arbor, MI 48109-0632, USA

[c] Department of Chemistry, University of Rochester, Rochester, NY 14627-0216, USA

Supporting information for this article is available on the WWW under http://dx.doi.org/10.1002/ejic.201402835.<smiles>O=C([O-])C(=O)O</smiles>

$\underset{\mathrm{OxOx}}{\stackrel{\mathrm{O}_{2}, \mathrm{H}^{\oplus}}{\longrightarrow}} 2 \mathrm{CO}_{2}+\mathrm{H}_{2} \mathrm{O}_{2}$

Despite the detailed knowledge of the OxOx structure, only limited information about the catalytic mechanism by which oxalate is oxidized to carbon dioxide has been uncovered. ${ }^{[7-13]}$ A mechanism for OxOx put forth by Bornemann et al. ${ }^{[5]}$ begins with the oxidation of a manganese(II) center to a $\mathrm{Mn}^{\mathrm{III}}$-superoxido species after binding to an oxalate ion (Scheme 1). Internal redox results in a $\mathrm{Mn}^{\mathrm{II}}$-superoxido species bonded to a one-electron-oxidized oxalate ion. $\mathrm{CO}_{2}$ is then lost to afford a $\mathrm{Mn}^{\mathrm{II}}$-superoxido-bound $\mathrm{CO}_{2}$ radical species. The next step invokes the formation of a peroxocarbonate anion, which decomposes in the presence of protons to release $\mathrm{H}_{2} \mathrm{O}_{2}$ and $\mathrm{CO}_{2}$ and regenerate the resting state (it should be noted that an alternative mechanism proposed by Whittaker et al. suggests that the active form of the enzyme is a $\mathrm{Mn}^{\mathrm{III}}$ species). ${ }^{[14]}$

There has been interest in the use of synthetic compounds to model the active site of OxOx. ${ }^{[15-18]}$ In the present work, we have employed the ligand 1-benzyl-4-acetato1,4,7-triazacyclononane (HL) to synthesize [MnLCl] (1), which serves as a model for the active site of $\mathrm{OxOx}$ (Scheme 2). ${ }^{[19-22]}$

In these studies, we will present the properties and reactivity of $\mathbf{1}$ toward oxalate ions and present evidence for a proposed mechanism for the catalytic decomposition of oxalate initiated by $\mathbf{1}$. 


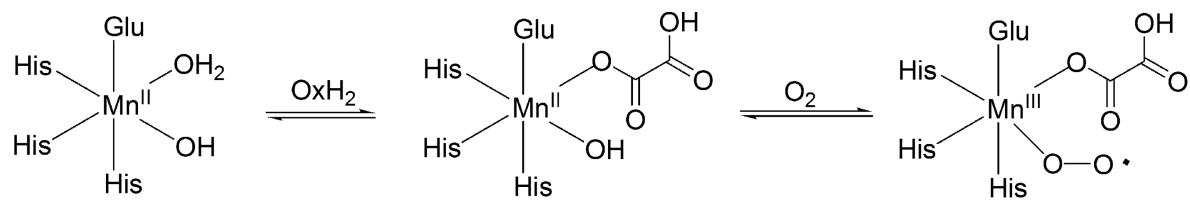

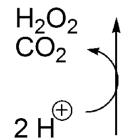

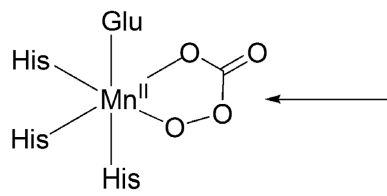

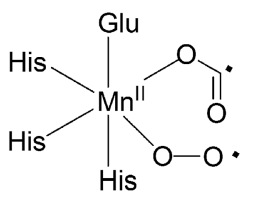<smiles>CC1OC(=O)C1C</smiles>

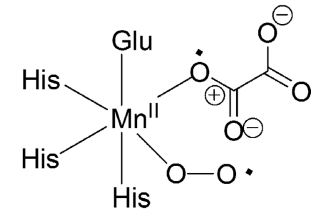

Scheme 1. Proposed mechanism for OxOx. ${ }^{[5]}$<smiles>O=C(O)CN1CCNCCN(Cc2ccccc2)CC1</smiles>

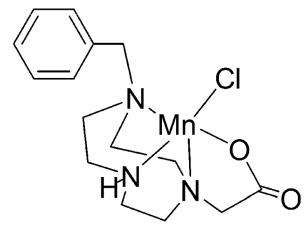

Scheme 2. Structures of LH and [MnLCl].

\section{Results and Discussion}

We have prepared the compound [MnLCl] (1) as a model

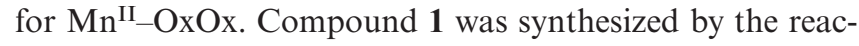
tion of $\mathrm{LH} \cdot 2 \mathrm{HCl}$ with $\mathrm{MnCl}_{2}$ in $\mathrm{MeCN} / \mathrm{MeOH}$ in the presence of triethylamine (4 equiv.). The compound was crystallized by evaporation under nitrogen at room temperature in the presence of a few drops of water. The water was added to slow down crystallization and improve the quality of the crystals. The crystal data and bond lengths for $\mathbf{1}$ are shown in Tables 1 and 2, respectively. The structure was refined as an inversion twin (53:47). The molecules align as one-dimensional chains parallel to the $a$ axis, and all atoms are in general positions. A cocrystallized water molecule was given half occupancy as an approximation. The solidstate structure of 1 consists of a $\mathrm{Mn}^{\mathrm{II}}$ ion bonded to three amine nitrogen atoms and one carboxylate oxygen atom from the ligand, and additional coordination to a carboxylate group from another unit results in seven-coordinate centers (Figure 1). The water molecules participate in hydrogen bonding with the coordinated chlorido ligand $[\mathrm{O}(3) \cdots \mathrm{Cl}(1)$, 3.047(8) A]. Additional hydrogen bonding is seen between

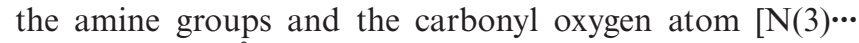
$\left.\mathrm{O}(2)^{\prime}, 2.952(5) \AA\right]$. The triamine ligand is modeled as disordered over two positions (58:42), and the benzyl group is modeled as disordered over three positions $(39: 35: 26){ }^{[23]}$
Table 1. Crystallographic data for $\mathbf{1} \cdot 0.5 \mathrm{H}_{2} \mathrm{O}$.

\begin{tabular}{ll}
\hline & $\mathbf{1} \cdot 0.5 \mathrm{H}_{2} \mathrm{O}$ \\
\hline Chemical formula & $\mathrm{C}_{15} \mathrm{H}_{23} \mathrm{ClMnN}_{3} \mathrm{O}_{2.5}$ \\
Formula weight $[\mathrm{g} / \mathrm{mol}]$ & 375.75 \\
Temperature $[\mathrm{K}]$ & $100(1)$ \\
$\lambda[\AA]$ & 0.71073 \\
Space group & $P 2_{1} 2_{1} 2_{1}$ \\
$a[\AA]$ & $8.2740(16)$ \\
$b[\AA]$ & $10.472(2)$ \\
$c[\AA]$ & $19.088(4)$ \\
$a\left[^{\circ}\right]$ & 90 \\
$\beta\left[^{\circ}\right]$ & 90 \\
$\gamma\left[^{\circ}\right]$ & 90 \\
$V\left[^{\circ} \AA^{3}\right]$ & $1654.0(6)$ \\
$\mathrm{Z}$ & 4 \\
$\mu\left[\mathrm{mm}^{-1}\right]$ & 0.973 \\
$D_{\text {calcd. }}\left[\mathrm{Mg} / \mathrm{m}^{3}\right]$ & 1.509 \\
$R 1[I>2 \sigma(I)]$ & 0.0646 \\
$w R 2[I>2 \sigma(I)]$ & 0.1459 \\
\hline
\end{tabular}

Table 2. Selected bond lengths $[\AA]$ and angles $\left[{ }^{\circ}\right]$ for $\mathbf{1} \cdot 0.5 \mathrm{H}_{2} \mathrm{O}$.

\begin{tabular}{llll}
\hline Distances & & & \\
\hline $\mathrm{Mn}(1)-\mathrm{N}(1)$ & $2.399^{[\mathrm{a}]}$ & $\mathrm{Mn}(1)-\mathrm{Cl}(1)$ & $2.4885(15)$ \\
$\mathrm{Mn}(1)-\mathrm{N}(2)$ & $2.425^{[\mathrm{a}]}$ & $\mathrm{Mn}(1)-\mathrm{O}(1)^{\prime}$ & $2.466(3)$ \\
$\mathrm{Mn}(1)-\mathrm{N}(3)$ & $2.268(3)$ & $\mathrm{Mn}(1)-\mathrm{O}(2)^{\prime}$ & $2.245(3)$ \\
$\mathrm{Mn}(1)-\mathrm{O}(1)$ & $2.207(3)$ & & \\
\hline Angles & & & \\
\hline $\mathrm{O}(1)-\mathrm{Mn}(1)-\mathrm{N}(1)$ & $70.7^{[\mathrm{a}]}$ & $\mathrm{N}(1)-\mathrm{Mn}(1)-\mathrm{N}(3)$ & $74.8^{[\mathrm{a}]}$ \\
$\mathrm{O}(1)-\mathrm{Mn}(1)-\mathrm{N}(2)$ & $97.7^{[\mathrm{a}]}$ & $\mathrm{N}(2)-\mathrm{Mn}(1)-\mathrm{N}(3)$ & $73.5^{[\mathrm{a}]}$ \\
$\mathrm{O}(1)-\mathrm{Mn}(1)-\mathrm{N}(3)$ & $146.13(13)$ & $\mathrm{Cl}(1)-\mathrm{Mn}(1)-\mathrm{N}(1)$ & $97.9^{[\mathrm{a}]}$ \\
$\mathrm{O}(1)-\mathrm{Mn}(1)-\mathrm{Cl}(1)$ & $90.90(12)$ & $\mathrm{Cl}(1)-\mathrm{Mn}(1)-\mathrm{N}(2)$ & $164.4^{[\mathrm{a}]}$ \\
$\mathrm{N}(1)-\mathrm{Mn}(1)-\mathrm{N}(2)$ & $73.5^{[\mathrm{a}]}$ & $\mathrm{Cl}(1)-\mathrm{Mn}(1)-\mathrm{N}(3)$ & $92.40(10)$
\end{tabular}

[a] Weighted averages based on contributions in the disordered structure.

The $\mathrm{Mn}-\mathrm{N}$ bond lengths (weighted average) for 1 (2.268$2.425 \AA$ ) are within the range of other known secondary and tertiary $\mathrm{Mn}-\mathrm{N}$ bond lengths $(2.19-2.68 \AA) .{ }^{[24-32]}$ The $\mathrm{Mn}-\mathrm{Cl}$ bond length $(2.4885 \AA)$ is also comparable to those in other chlorido-containing $\mathrm{Mn}^{\mathrm{II}}$ compounds. ${ }^{[26,33,34]} \mathrm{A}$ 


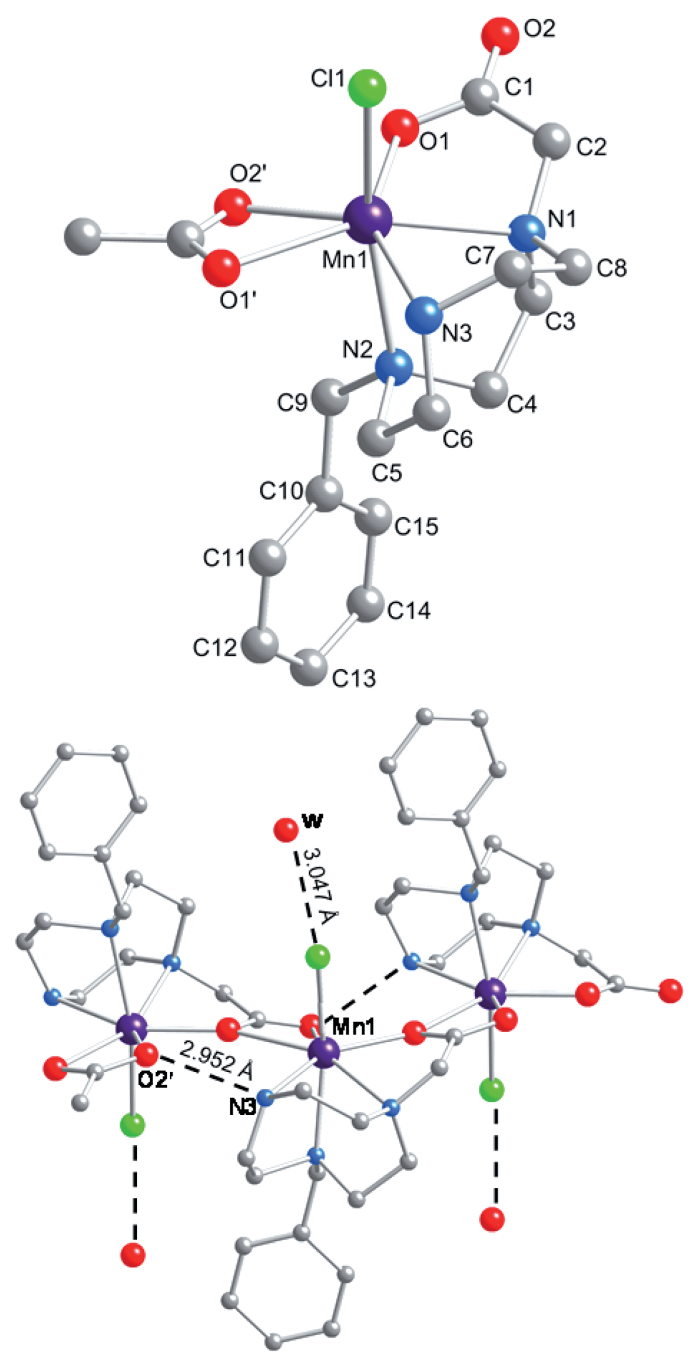

Figure 1. X-ray structure of [MnLCl] (1, top) with an adjoining carboxylate ligand and extended solid-state structure (bottom). The water molecules are denoted as w. $\mathrm{H}$ atoms have been removed for clarity. Only the primary contributors in the disordered structure are shown for clarity.

similar structure $\left[\mathrm{Mn}(\mathrm{TCMA})\left(\mathrm{H}_{2} \mathrm{O}\right)\right] \mathrm{CF}_{3} \mathrm{SO}_{3}(2 ; \mathrm{TMCA}=$ 1,4,7-triazacyclononane- $N$-acetic acid) was reported by Pecoraro and co-workers and features a manganese complex with a carboxylate-functionalized 1,4,7-triazacyclononane (tacn) ligand. ${ }^{[17]}$ The primary difference in the structures is that 1 contains a chlorido ligand bonded to the Mn center instead of a water ligand seen in 2 . The $\mathrm{Mn}-\mathrm{O}(1)$ bond length in $\mathbf{1}$ is 2.207(3) $\AA$, whereas the same distance is 2.214(2) $\AA$ in 2.

At low temperatures, native recombinant $\mathrm{OxOx}^{[35]}$ gives rise to a broad electron paramagnetic resonance (EPR) spectrum dominated by a strong six-line ${ }^{55} \mathrm{Mn}(I=5 / 2)$ multiplet at $g \approx 2$ with nuclear hyperfine splitting $\left(a^{\mathrm{Mn}}=\right.$ $95 \mathrm{G})$ consistent with a high-spin $\mathrm{Mn}^{\mathrm{II}}$ center $(S=5 / 2)$ in approximately octahedral geometry.

Although $\mathbf{1}$ is insoluble in acetonitrile, it becomes soluble in the presence of excess bis(tetrabutylammonium) oxalate (TBAO). The EPR spectrum of a mixture of 1 and 20 equiv. of TBAO in 1:1 acetonitrile/butyronitrile is shown in Figure 2 (a). The spectrum is consistent with a mononuclear $\mathrm{Mn}^{\mathrm{II}}$ species with $g=2$. Cyclic voltammetry studies on $\mathbf{1}$ in acetonitrile and in the presence of 2 equiv. of TBAO only revealed an irreversible anodic wave at ca. $660 \mathrm{mV}$ (vs. Ag/ $\mathrm{AgCl}$, see Figure S1). Such behavior indicates that the adduct becomes unstable upon oxidation. The lack of a cathodic wave also suggests that the Mn center has reverted to $\mathrm{Mn}^{\mathrm{II}}$.

(a)

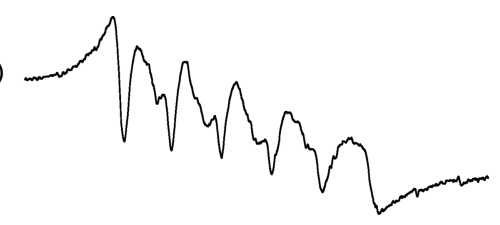

(b)

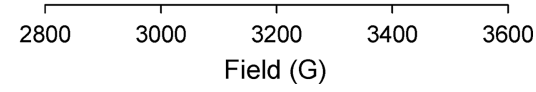

Figure 2. X-band EPR spectrum $(77 \mathrm{~K})$ of (a) $\mathbf{1}+20$ equiv. of TBAO in 1:1 MeCN/butyronitrile in the absence of oxygen and (b) the spectrum $100 \mathrm{~min}$ after oxygenation of the sample. Spectrometer settings: microwave frequency: $9.28 \mathrm{GHz}$, microwave power: $0.22 \mathrm{~mW}$, modulation frequency: $100 \mathrm{kHz}$; modulation amplitude: $3.2 \mathrm{G}$, gain: $1 \times 10^{4} ;[\mathrm{MnLCl}]=1 \mathrm{~mm}$.

Although others have reported structural models for OxOx, ${ }^{[15-18]}$ to the best of our knowledge, no group has successfully provided a model complex that is able to initiate degradation of the natural substrate. Such a system could help to elucidate the mechanism for OxOx. Toward this end, we have tested our model complex for reactivity toward oxalate. The anaerobic mixing of 1 with 20 equiv. of TBAO in acetonitrile affords a colorless solution, which becomes dark pink with an absorption band at $\lambda=480 \mathrm{~nm}$ and a shoulder at $\lambda=530 \mathrm{~nm}$ upon exposure to oxygen at $25^{\circ} \mathrm{C}$ (Figure 3 ). The rate for oxygenation for $\mathbf{1}$ is sluggish, and the complete formation of the two bands takes over $100 \mathrm{~min}$. At $100 \mathrm{~min}$, the $480 \mathrm{~nm}$ band becomes a shoulder $\left(\varepsilon=230 \mathrm{M}^{-1} \mathrm{~cm}^{-1}\right)$, and the $530 \mathrm{~nm}$ band $\left(\varepsilon=240 \mathrm{M}^{-1} \mathrm{~cm}^{-1}\right)$ becomes larger. At this point, the EPR spectrum of the reaction mixture (after dilution to ca. $1 \mathrm{~mm}$ with butyronitrile) was silent (Figure 2, b). This suggests that the primary species has a $\mathrm{Mn}^{\mathrm{III}}$ center, as $\mathrm{Mn}^{\mathrm{II}}$ and $\mathrm{Mn}^{\mathrm{IV}}$ are both EPR-active. Attempts to detect a $\mathrm{Mn}^{\mathrm{III}}$-superoxido species were unsuccessful, likely as a result of the short-lived nature of such a species. The persistence of the intermediate color for several days suggests that the Mn species either remains or is repeatedly regenerated. The absorption bands for the pink species are likely due to ligand-field $d-d$ transitions from a geometrically distorted $\mathrm{Mn}^{\mathrm{III}}$ species. ${ }^{[36-38]}$ After $100 \mathrm{~min}$, the two bands continue to grow slightly (Figure $\mathrm{S} 2$ ); the $530 \mathrm{~nm}$ band becomes larger at $20 \mathrm{~h}$, and the $480 \mathrm{~nm}$ band finally dominates at $60 \mathrm{~h}$. 


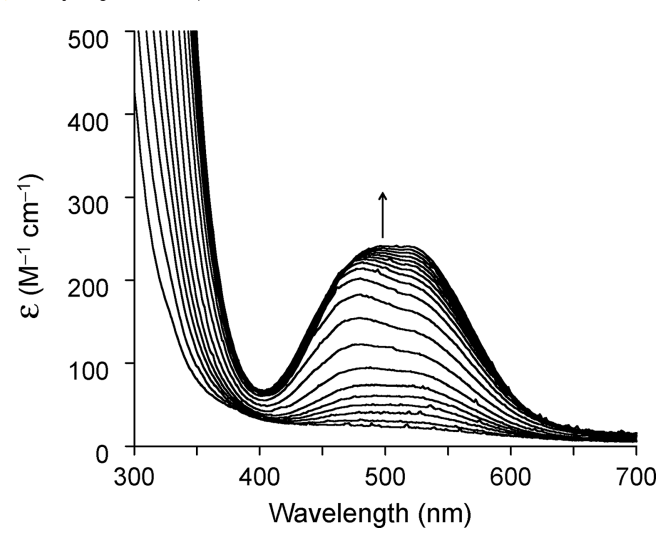

Figure 3. UV/Vis spectrum for the oxygenation of $\mathbf{1}$ in acetonitrile $(1.5 \mathrm{~mm})$ in the presence of 20 equiv. of TBAO. The elapsed time between the bottom and top traces is $100 \mathrm{~min}$.

When 1 is reacted with 20 equiv. of TBAO in acetonitrile on a larger scale in the presence of excess oxygen at $25^{\circ} \mathrm{C}$, the TBAO is degraded in a catalytic manner. A time course for the disappearance of TBAO is shown in Figure 4 (squares). From the graph, it is apparent that $89 \%$ of TBAO has been degraded by 1 after $36 \mathrm{~h}$. A reaction mixture containing $\mathrm{MnCl}_{2}$ and $\mathrm{TBAO}$ was run under the same conditions, and catalytic decomposition of oxalate also occurred. This result has implications for the proposed mechanism described below. However, the initial decomposition rate with 1 was faster than that with $\mathrm{MnCl}_{2}$. Therefore, the presence of the ligand $\left(\mathrm{L}^{-}\right)$could help to solubilize the intermediate species and, thus, help to accelerate the overall reaction. However, it should be noted that $\mathrm{MnCl}_{2}$ is quite effective, and the overall results for oxalate decomposition are comparable. We have also determined that the reaction requires ambient light, as the reaction rate is significantly slower when the lights are turned off. This is understandable given the known light sensitivity of manganese oxalate complexes. ${ }^{[38-40]}$ A control reaction (lacking Mn catalyst) was also run under the same conditions, and a minor amount of the TBAO was degraded over the same time period (Figure 4).

In the catalytic studies of 1, GC-MS analysis of the headspace indicated that $\mathrm{CO}_{2}$ was a product from the reaction, as is the case for OxOx. $\mathrm{CO}_{2}$ measurements were made on the reaction headspace by using an FTIR gas cell and monitoring the $\mathrm{CO}_{2}$ asymmetric stretching vibration $(\tilde{v} \approx$ $2350 \mathrm{~cm}^{-1}$ ). The absorbance was integrated between $\tilde{v}=$ $2390-2280 \mathrm{~cm}^{-1}$ and converted to $\mathrm{mmol}$ of $\mathrm{CO}_{2}$ by using the ideal gas law. A standard curve (Figure S3) was prepared by injecting known amounts of $\mathrm{CO}_{2}$ into matched Schlenk flasks containing $10 \mathrm{~mL}$ of acetonitrile and attaching the flasks to the evacuated gas cell. In a typical measurement, a $25 \mathrm{~mL}$ Schlenk flask was charged with $\mathbf{1}$ (7.3 mg, $0.02 \mathrm{mmol}$ ). After the flask was purged with dry oxygen, TBAO $(22.9 \mathrm{mg}, 0.04 \mathrm{mmol})$ dissolved in acetonitrile $(10 \mathrm{~mL})$ was added. The flask was stoppered, and the reaction was allowed to run to completion. By this procedure, we determined that 1 reacts with 2 equiv. of TBAO in the presence of $\mathrm{O}_{2}$ to initially afford ca. 0.7 equiv. of

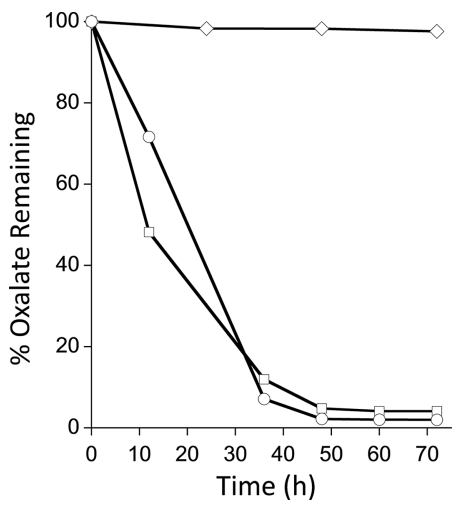

Figure 4. Time course for the decomposition of oxalate (TBAO, $0.28 \mathrm{M})$ catalyzed by $1(0.014 \mathrm{M}, \square)$ and $\mathrm{MnCl}_{2}(0.014 \mathrm{M}, \bigcirc)$ in acetonitrile at $25^{\circ} \mathrm{C}$. The control reaction $(\diamond$, no catalyst) is also shown.

$\mathrm{CO}_{2}$ /oxalate. As the mechanism for oxalate degradation suggested by Bornemann et al ${ }^{[5]}$ requires a proton source, we injected a dilute solution of $\mathrm{HCl}$, and this resulted in the formation of additional $\mathrm{CO}_{2}$ to afford a total of ca. 2 equiv. of $\mathrm{CO}_{2}$ released per oxalate ion consumed (Table 3). Two additional experiments confirmed this result, and a reaction with 4 equiv. of TBAO also resulted in the formation of ca. 2 equiv. of $\mathrm{CO}_{2}$ released per oxalate ion consumed.

Table 3. Quantification of $\mathrm{CO}_{2}$ liberated from the decomposition of TBAO catalyzed by 1 .

\begin{tabular}{lccccc}
\hline Trial & $\begin{array}{c}{[\mathrm{MnLCl}]} \\
{[\mathrm{mmol}]}\end{array}$ & $\begin{array}{c}\mathrm{TBAO} \\
{[\mathrm{mmol}]}\end{array}$ & $\begin{array}{c}\mathrm{CO}_{2}[\mathrm{mmol}] \\
\text { After } \mathrm{H}^{+}[\mathrm{a}]\end{array}$ & $\begin{array}{c}\text { Total } \mathrm{CO}_{2} \\
{[\mathrm{mmol}]}\end{array}$ \\
\hline 1 & 0.020 & 0.042 & 0.031 & 0.055 & 0.086 \\
2 & 0.020 & 0.043 & 0.029 & 0.056 & 0.085 \\
3 & 0.020 & 0.041 & 0.026 & 0.055 & 0.081 \\
4 & 0.020 & 0.083 & 0.052 & 0.120 & 0.170 \\
\hline
\end{tabular}

[a] $2 \mathrm{mmol}(2 \mathrm{~N} \mathrm{HCl})$.

Although the oxidation of oxalate ions to form $\mathrm{CO}_{2}$ by manganese(III) species in aqueous solution has been known for some time, ${ }^{[41-44]}$ no studies have been reported for the manganese(II)-catalyzed oxidation of oxalate ions with oxygen as the oxidant under nonaqueous conditions. Under aqueous aerobic conditions, $[\mathrm{MnLCl}]$ is unreactive towards oxalate.

For the manganese(III)-induced oxidation of oxalate under acidic conditions, Taube previously detected the production of $\mathrm{H}_{2} \mathrm{O}_{2}$ by iodometry. ${ }^{[41]}$ As there was the potential for the formation of a peroxide species during the course of our reaction, we also tested for its presence by a literature method for iodometry. ${ }^{[45]}$ Before testing, the reaction mixtures were first treated with 30 equiv. of $\mathrm{HCl}$ relative to catalyst content. From these measurements, we determined that $0.6-0.8$ equiv. of peroxide was present relative to 1 during the course of the reaction with the higher concentration at the end of the reaction. To confirm the presence of peroxide, we employed peroxide strips (EM Quant ${ }^{\circledR}$ ) and obtained a positive result. To determine if the peroxide species detected by iodometry and with the peroxide strips 
was $\mathrm{H}_{2} \mathrm{O}_{2}$, we tested the reaction mixture with a hydrogen peroxide specific fluorescence probe (Naphtho-Peroxyfluor1) according to a published method. ${ }^{[46]}$ The results were negative for hydrogen peroxide in all cases. As the probe is highly selective, the test was considered to be conclusive evidence that $\mathrm{H}_{2} \mathrm{O}_{2}$ was not the peroxide species formed. In accordance with this result, no anodic wave $\left(E_{\mathrm{a}}=0.68 \mathrm{~V}\right.$ vs. $\mathrm{Ag} / \mathrm{AgCl}$ ) for $\mathrm{H}_{2} \mathrm{O}_{2}{ }^{[47]}$ was observed for the reaction mixtures (a positive result was obtained when the reaction mixture was spiked with $\mathrm{H}_{2} \mathrm{O}_{2}$ ). These results indicate that although a peroxide species is formed during the course of the catalytic reaction, it is not hydrogen peroxide. There is some support for the formation of a $\mu$-1,2-peroxido dimanganese(III) species during the catalytic cycle. Such a species has been recently characterized by X-ray crystallography. ${ }^{[48,49]}$ Although electrospray ionization mass spectrometry (ESI-MS, negative mode) did not reveal the presence of $\left[\mathrm{L}(\mathrm{ox}) \mathrm{Mn}^{\mathrm{III}}-\mathrm{O}-\mathrm{O}-\mathrm{Mn}^{\mathrm{III}}(\mathrm{ox}) \mathrm{L}\right]^{2-} 10 \mathrm{~min}$ after the reaction mixture was oxygenated, we detected (Figure S4) a deprotonated form of this species as a monoanion (see below).

An MS/MS experiment (Figure S5) on this species shows fragmentation with the release of a $[\mathrm{MnL}]$ species along with a monoprotonated oxalate anion $\left([\mathrm{oxH}]^{-}\right)$. The absence

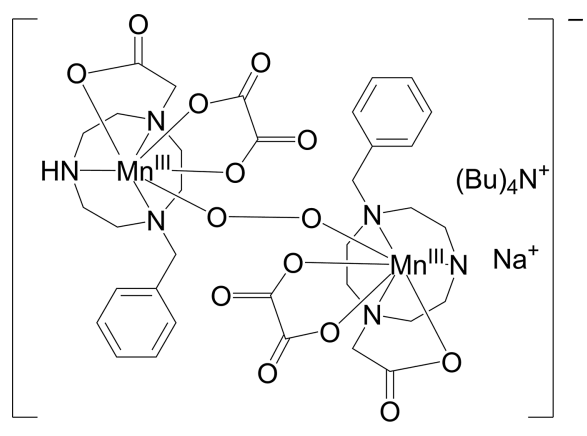

1134.43 of this species after $1 \mathrm{~d}$ makes this an unlikely candidate for the peroxide species that is detected or the pink species observed in the reaction. Other species observed in the reaction mixture (see Figure S4) during this timeframe are shown below.

These results confirm the formation of the $\left[\mathrm{Mn}^{\mathrm{II}} \mathrm{L}(\mathrm{ox})\right]^{-}$ species $(m / z=419.09)$ but also suggest that a more complex set of reactions occurs during this process. At $24 \mathrm{~h}$, the primary species identified are $[\mathrm{oxH}]^{-}(\mathrm{m} / \mathrm{z}=88.99)$ and $\left[\mathrm{Mn}^{\mathrm{III}}(\mathrm{ox})_{2}\right]^{-}(m / z=230.9)$. This indicates that the pink species is likely to be an EPR-silent $\left[\mathrm{Mn}^{\mathrm{III}}(\mathrm{ox})_{2}\right]^{-}$species and that catalysis mainly involves photodecomposition of this complex, a process that is documented in the literature. ${ }^{[38-40]}$ The low dielectric constant of acetonitrile is expected to destabilize the formation of $\left[\mathrm{Mn}^{\mathrm{III}}(\mathrm{ox})_{3}\right]^{3-}$; therefore, $\left[\mathrm{Mn}^{\mathrm{III}}(\mathrm{ox})_{2}\right]^{-}$is observed.

FTIR spectroscopy was used to analyze the catalytic reaction mixture after the TBAO was consumed. A portion of the reaction mixture was evaporated to dryness and pressed into a $\mathrm{KBr}$ pellet. From this experiment, we ob-

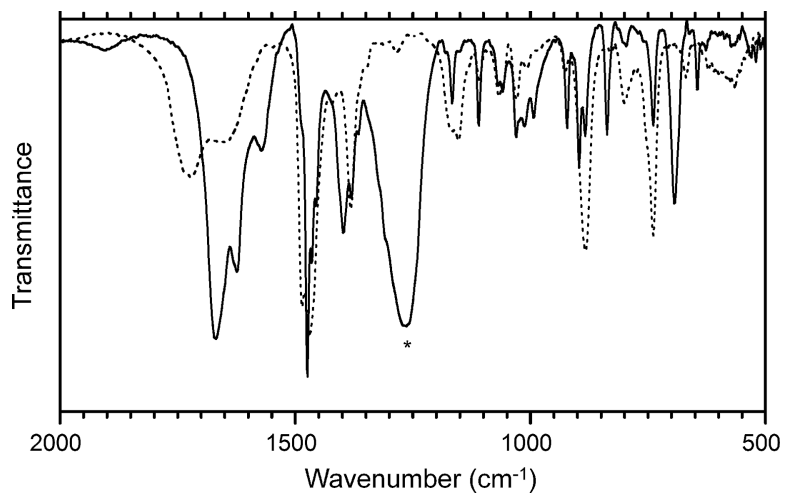

Figure 5. FTIR spectra (KBr pellet) of the final evaporated catalytic reaction mixture $(-)$ and the same mixture treated with dilute acid before evaporation (---).

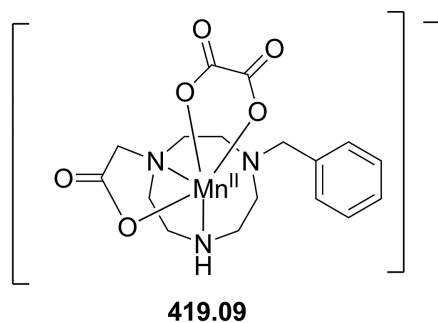

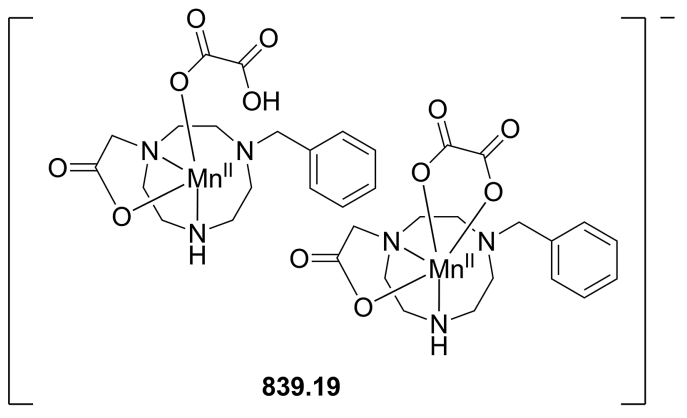

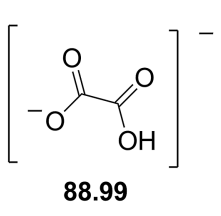<smiles>CCO[N+]1(C)OC(=O)C(C(=O)O)C(=O)O1</smiles>

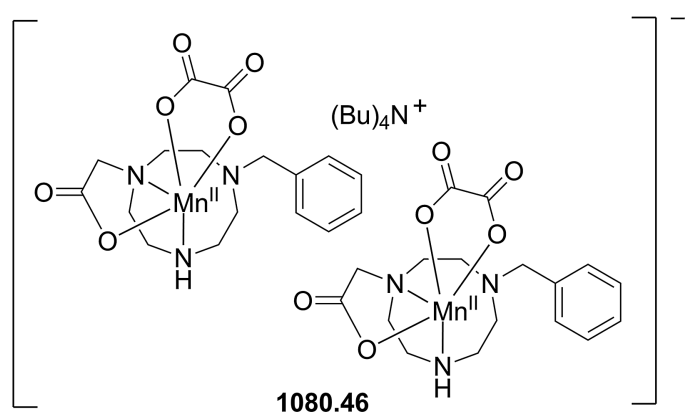




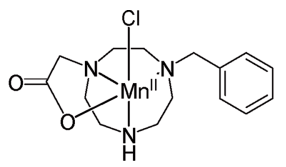

(a) ${ }_{\mathrm{Cr}} \mathrm{ox}^{2-}$

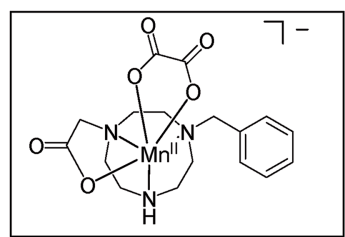

(b) $f^{0_{2}}$
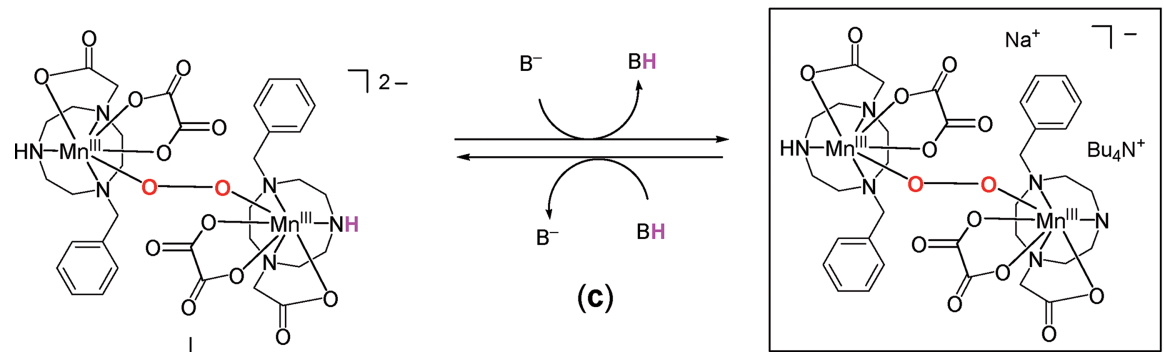

(d) $\mathrm{o}_{2}^{2-}$

(c)
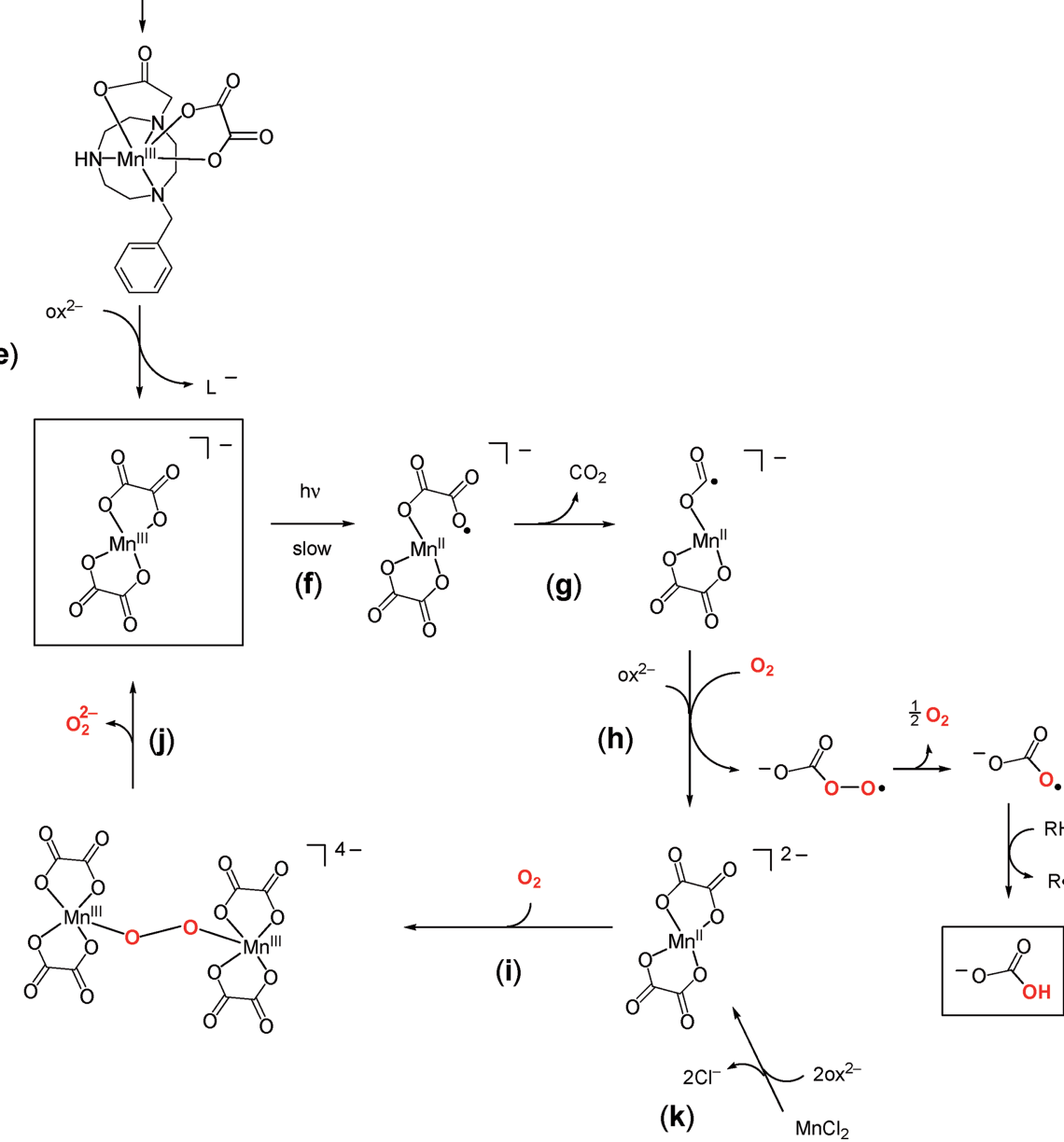

Scheme 3. Proposed mechanism for the catalytic turnover of oxalate by [MnLCl]. Species identified by ESI-MS are indicated in boxes. 
served a large band at $\tilde{v} \approx 1265 \mathrm{~cm}^{-1}$, which was missing when the reaction mixture was first treated with acid before analysis (Figure 5).

This band is near the region for a carbonate stretching vibration the $v\left(\mathrm{CO}_{3}\right)$ band for $\left[(n \mathrm{Bu})_{4} \mathrm{~N}_{2} \mathrm{CO}_{3}\right.$ is reported at $\left.\tilde{v} \approx 1300 \mathrm{~cm}^{-1}\right\} .{ }^{[50]} \mathrm{A}$ carbonate species has also been detected by ${ }^{13} \mathrm{C}$ NMR spectroscopy (Figure S6). This explains the formation of additional $\mathrm{CO}_{2}$ upon the injection of dilute acid into the reaction mixture.

To explain the catalysis in our system and the above analytical and spectroscopic data, we propose the mechanism shown in Scheme 3. First, an oxalate ion binds to $\left[\mathrm{LMn}^{\mathrm{II}} \mathrm{Cl}\right]$ to generate $\left[\mathrm{LMn}^{\mathrm{II}}(\mathrm{ox})\right]^{-}$(Scheme 3 (a), the presence of this species in the reaction mixture has been confirmed by negative-mode ESI-MS, $m / z=419.09$, Figure S4). Next, oxygen binds to the complex to form a $\mathrm{Mn}^{\mathrm{III}}$-superoxido species, which rapidly reacts with another $\left[\mathrm{L}(\mathrm{ox}) \mathrm{Mn}^{\mathrm{II}}\right]^{-}$species to generate a $\mu$-1,2-peroxidodimanganese(III) complex, $\left[\mathrm{L}(\mathrm{ox}) \mathrm{Mn}{ }^{\mathrm{III}}-\mathrm{O}-\mathrm{O}-\mathrm{Mn}^{\mathrm{III}}(\mathrm{ox}) \mathrm{L}\right]^{2-}$ (Scheme 3, b). As indicated above, this complex was not observed in the MS experiment, but a deprotonated form was. Such a species could be in equilibrium with the protonated form and this is shown in Scheme 3 (c). The loss of a peroxide dianion (Scheme 3, d) could then generate charge-neutral [L(ox)$\left.\mathrm{Mn}^{\mathrm{III}}\right]$. The excess oxalate in the reaction mixture would then displace the ligand (Scheme 3, e) to yield [(ox $)_{2}$ $\left.\mathrm{Mn}^{\mathrm{III}}\right]^{-}$, which is clearly visible (between $10 \mathrm{~min}$ and $48 \mathrm{~h}$; Figures S4, S7, and S8). As the photoactivation of this species is slow (Scheme 3, f), this is probably the pink species that we observed in the UV/Vis spectrum and explains its persistence throughout the catalytic cycle. The radical species formed after photoactivation and the concomitant reduction of the manganese(III) center to manganese(II) is believed to produce $\mathrm{CO}_{2}(\mathrm{~g})$ and a coordinated $\mathrm{CO}_{2}$ radical (Scheme 3, g). ${ }^{[14,38-40,51]}$ In the presence of excess $\mathrm{O}_{2}$, the $\mathrm{CO}_{2}$ radical would immediately react to generate a peroxy carbonate intermediate. Two of these species could then react to release oxygen and a carbonate radical, which would then abstract an $\mathrm{H}$ atom from an organic substrate to ultimately yield hydrogen carbonate, a product that is clearly observed by ESI-MS (Figure S9). An oxalate ligand can then bind to $\left[(\mathrm{ox}) \mathrm{Mn}^{\mathrm{II}}\right]$ to form $\left[(\mathrm{ox})_{2} \mathrm{Mn}^{\mathrm{II}}\right]^{2-}$ (Scheme 3, h), which would react with oxygen to form the $1,2-\mu$-peroxido species, $\quad\left[(\mathrm{ox})_{2} \mathrm{Mn}^{\mathrm{III}}-\mathrm{O}-\mathrm{O}-\mathrm{Mn}^{\mathrm{III}}(\mathrm{ox})_{2}\right]^{4-} \quad$ (Scheme 3, i). The release of the peroxide anion would regenerate $\left[(\mathrm{ox})_{2^{-}}\right.$ $\left.\mathrm{Mn}^{\mathrm{III}}\right]^{-}$(Scheme 3, j), and the cycle would continue until the oxalate ions are consumed. After $4 \mathrm{~d}$, the reaction mixture was analyzed by ESI-MS (Figure S10), and the observation of $\left[\mathrm{Mn}^{\mathrm{III}}\left(\mathrm{HCO}_{3}\right)_{3} \mathrm{Cl}\right]^{-}(\mathrm{m} / \mathrm{z}=273.44)$ and $\left[\mathrm{Mn}^{\mathrm{IV}}(\mathrm{OH})\left(\mathrm{HCO}_{3}\right)_{3} \mathrm{Cl}\right]^{-}(\mathrm{m} / \mathrm{z}=290.45)$ as the primary products suggests that the peroxide dianion formed during the process further oxidizes the manganese(III) center to manganese(IV). The abovementioned mechanism suggests that catalysis could be achieved in the absence of the ligand $\mathrm{L}^{-}$, and this has already been shown in Figure 4. When $\mathrm{MnCl}_{2}$ is oxygenated in the presence of 20 equiv. of TBAO and monitored by UV/Vis spectroscopy, a pink species is generated (Figure S11) with a UV/Vis spectrum similar to that of 1 (Figure 3). The implications are that first $\left[\mathrm{Mn}^{\mathrm{II}}(\mathrm{ox})_{2}\right]^{2-}$ is formed and can then feed into the proposed cycle shown in Scheme $3(\mathrm{k})$.

To examine the fate of the oxygen during the catalytic cycle, we employed ${ }^{18} \mathrm{O}_{2}$. In a typical experiment, a solution of $1(0.14 \mathrm{~mol})$ in acetonitrile $(10 \mathrm{~mL})$ in a $25 \mathrm{~mL}$ Schlenk flask was mixed with 20 equiv. of TBAO under nitrogen. ${ }^{18} \mathrm{O}_{2}(25 \mathrm{~mL}, 98.5$ atom- $\%)$ was carefully introduced, and the reaction mixture was stirred for $3 \mathrm{~d}$ in the presence of light at ambient temperature. A sample $(10 \mu \mathrm{L})$ of the headspace gas was removed from the reaction flask through a septum affixed to the sidearm and quickly injected into the GC-MS instrument. Repeated injections gave a relative mixture of ${ }^{16} \mathrm{OC}^{16} \mathrm{O}(71 \%),{ }^{18} \mathrm{OC}^{16} \mathrm{O}(25 \%)$, and ${ }^{18} \mathrm{OC}^{18} \mathrm{O}$ $(4 \%)$.

The analysis of the reaction mixture by ESI-MS revealed the presence of $\mathrm{HCO}_{3}^{-}$anions with ${ }^{18} \mathrm{O}$ incorporation as follows: $\mathrm{HC}^{16} \mathrm{O}_{3}^{-} \quad(77 \%), \quad \mathrm{HC}^{18} \mathrm{O}^{16} \mathrm{O}_{2}^{-}(19 \%)$, and $\mathrm{HC}^{18} \mathrm{O}_{2}{ }^{16} \mathrm{O}^{-}(4 \%)$. The predicted distribution based on full adherence to the proposed mechanism shown in Scheme 3 would be ${ }^{16} \mathrm{OC}^{16} \mathrm{O}(100 \%)$ and $\mathrm{HC}^{18} \mathrm{O}^{16} \mathrm{O}_{2}^{-}(100 \%)$. As this is not observed, ${ }^{18} \mathrm{O}$ scrambling between $\mathrm{CO}_{2}$ and $\mathrm{HCO}_{3}{ }^{-}$is probably in effect. Such scrambling has been observed previously ${ }^{[52]}$ and is accounted for by [Equation (2)].

$\mathrm{CO}_{2}+\mathrm{OH}^{-} \rightleftharpoons \mathrm{HCO}_{3}^{-}$

The catalytic mechanism for OxOx has been previously investigated through DFT calculations. ${ }^{[1]}$ The initial coordination of the oxalate ion to the manganese(II) center in both a monodentate and a chelating fashion was explicitly considered. In the monodentate model, the binding of oxygen at an open site on the manganese(II) center results in the release of the first $\mathrm{CO}_{2}$ molecule. A Mn ${ }^{\mathrm{III}}-\mathrm{OOH}$ species results along with a coordinated formyl radical. The transfer of an electron from the formyl radical to the manganese center results in the formation of a manganese(II) center and the products. In our model complex, the oxalate ion is believed to bind in a chelating fashion initially. The sixcoordinate species can still react with oxygen to initially generate a [L(ox) $\left.\mathrm{Mn}^{\mathrm{III}}-\mathrm{OO}\right]$ species, which rapidly reacts with $\left[\mathrm{LMn}^{\mathrm{II}}(\mathrm{ox})\right]^{-}$to form $[\mathrm{L}(\mathrm{ox}) \mathrm{Mn}-\mathrm{O}-\mathrm{O}-\mathrm{Mn}(\mathrm{ox}) \mathrm{L}]^{2-}$. The release of the peroxide ion results in $\left[\mathrm{LMn}^{\mathrm{III}}(\mathrm{ox})\right]$. In OxOx, the formation of a $\mu-1,2$-peroxido species is prohibited owing to the isolation of the manganese centers; therefore, in the enzyme, the initial superoxide intermediate can clearly be directed for attack on the coordinated oxalate ligand. With our model studies, we have shown that the formation of a $\mathrm{Mn}^{\mathrm{III}}-$ (ox) species is sufficient to generate a $\mathrm{CO}_{2}$ molecule in the presence of light.

\section{Conclusions}

We present herein the first example of a structural OxOx model compound, which ultimately effects catalytic decomposition of oxalate ions. In the solid state, $[\mathrm{MnLCl}](\mathbf{1})$ exists as a coordination polymer. In acetonitrile (in the pres- 
ence of excess TBAO), $\mathbf{1}$ becomes monomeric. In the presence of oxygen, 1 effects the degradation of oxalate ions in a catalytic manner and liberates 2 equiv. of $\mathrm{CO}_{2}$ per oxalate ion after acidification of the final reaction mixture. During catalysis, EPR spectroscopy studies suggest the initial formation of a short-lived $\mathrm{Mn}^{\mathrm{III}}$-superoxido intermediate followed by a longer-lived pink $\mathrm{Mn}^{\mathrm{III}}$ species. Thus, the 1-(ox) adduct effectively mimics the first step in the OxOx catalytic cycle. The formation of a $\mu-1,2$-peroxido species and the eventual release of the peroxide ion yields neutral $\left[\mathrm{LMn}^{\mathrm{III}}(\mathrm{ox})\right]$. Various spectroscopic and analytic studies support the presence of a peroxide species in the reaction mixture. On the basis of ESI-MS studies, it is evident that the ligand in $\left[\mathrm{LMn}^{\mathrm{III}}(\mathrm{ox})\right]$ is subsequently displaced by oxalate ions to afford $\left[\mathrm{Mn}^{\mathrm{III}}(\mathrm{ox})_{2}\right]^{-}$, which was shown to be catalytically competent through slow photodecomposition to generate $\mathrm{CO}_{2}$, a hydrogen carbonate anion, and a manganese(II) species. The manganese(II) species then binds to an oxalate ion to ultimately regenerate $\left[\mathrm{Mn}^{\mathrm{III}}(\mathrm{ox})_{2}\right]^{-}$, which continues in the cycle until the oxalate is consumed.

\section{Experimental Section}

General Considerations: Oxalic acid, Dowex ${ }^{\circledR} 50 \mathrm{WX} 2$ (dry mesh 50-100), and $\mathrm{MnCl}_{2}$ were purchased from Acros Organics. Bis(pinacolato)diboron, potassium acetate, tetrabutylammonium hydroxide $(40 \mathrm{wt} .-\mathrm{\%}),\left[\mathrm{Pd}(\mathrm{dppf}) \mathrm{Cl}_{2}\right][\mathrm{dppf}=$ bis(diphenylphosphino)ferrocene], $N$-phenylbis(trifluoromethanesulfonimide), $N, N^{\prime}$ diisopropylethylamine, and naphthofluorescein were purchased from Sigma-Aldrich. Acetonitrile, diethyl ether, $N, N$-dimethylformamide (DMF), dichloromethane, and tetrahydrofuran were purified with an Innovative Technologies, Inc. solvent-purification system. Methanol was distilled from magnesium methoxide under a nitrogen atmosphere and stored over molecular sieves $(3 \AA)$. $\mathrm{LH} \cdot 2 \mathrm{HCl}$ was synthesized by a literature method. ${ }^{[22]}$ Naphtho-Peroxyfluor-1 was synthesized according to the method of Chang et al. ${ }^{[46]}$ Triethylamine was distilled from $\mathrm{CaH}_{2}$ under nitrogen. All other reagents were purchased from commercial sources and used as received. Manipulations of air-sensitive compounds were performed by standard Schlenk techniques or in a nitrogen-filled glovebox. Crystalline samples were pulverized and heated in vacuo before submission for elemental analysis (Atlantic Microlabs, Inc.).

[MnLCl] (1): To a solution of $\mathrm{LH} \cdot 2 \mathrm{HCl}(420 \mathrm{mg}, 1.20 \mathrm{mmol})$ in $\mathrm{CH}_{3} \mathrm{CN}(10 \mathrm{~mL})$ was added triethylamine $(486 \mathrm{mg}, 4.80 \mathrm{mmol}$, 4 equiv.). To this stirring ligand solution was slowly added $\mathrm{MnCl}_{2}$ (151 mg, $1.20 \mathrm{mmol})$ dissolved in methanol $(2 \mathrm{~mL})$. The mixture was stirred for $30 \mathrm{~min}$, and precipitation occurred. The precipitate was collected by filtration, washed with diethyl ether, and dried under vacuum. X-ray quality crystals of $\mathbf{1}$ were obtained by the slow evaporation of an acetonitrile solution of $\mathbf{1}$ containing a few drops of water under nitrogen, yield $382.6 \mathrm{mg}$ (87.8\%). FTIR (KBr): $\tilde{v}=3375$ (s, br), 3300 (s), 2842 (m), 1584 (vs, $v_{\mathrm{CO}}$ ), 1441 (s), 1325 (m), 1225 (m), 1100 (m), $1075(\mathrm{~m}), 1033(\mathrm{~m}), 983(\mathrm{~m}), 933(\mathrm{~m})$, $825(\mathrm{~m}), 808(\mathrm{~m}), 767(\mathrm{~m}), 717(\mathrm{~s}), 650(\mathrm{~m}) \mathrm{cm}^{-1} \cdot \mathrm{C}_{15} \mathrm{H}_{22} \mathrm{ClMnN}_{3} \mathrm{O}_{2}$ (366.75): calcd. C 49.12, H 6.05, N 11.46; found C 49.10, H 6.51, N 11.52.

Bis(tetrabutylammonium) Oxalate (TBAO): TBAO was prepared by a modified literature method. ${ }^{[53]}$ To oxalic acid $(5.01 \mathrm{~g}, 0.0556 \mathrm{~mol})$ dissolved in methanol $(40 \mathrm{~mL})$ was added tetrabutylammonium hydroxide (40 wt.- $\%, 72.1 \mathrm{~mL}, 2$ equiv.). After $2 \mathrm{~h}$ of stirring, the solvent was removed under reduced pressure to yield a gelatinous material. The remaining solvent was removed by vacuum distillation at $50-55^{\circ} \mathrm{C}(0.025$ Torr $)$ to afford a white solid, which was placed under high vacuum at $40{ }^{\circ} \mathrm{C}$ for $14 \mathrm{~h}$. The product was collected under dry nitrogen, yield $21.6 \mathrm{~g}(67.2 \%) .{ }^{1} \mathrm{H} \quad \mathrm{NMR}$ (400 MHz, [D]dichloromethane): $\delta=0.9$ (t, $24 \mathrm{H}$ ), 1.39 (sext, 16 $\mathrm{H}), 1.60$ (pent, $16 \mathrm{H}), 3.37(\mathrm{~m}, 16 \mathrm{H}) \mathrm{ppm} .{ }^{13} \mathrm{C}\{\mathrm{H}\}$ NMR $\left(100 \mathrm{MHz}, \mathrm{D}_{2} \mathrm{O}\right): \delta=13.46,19.76,23.74,58.74,174.11 \mathrm{ppm}$.

X-ray Crystallography: Compound $\mathbf{1}$ crystallized as colorless blocks by slow evaporation of an acetonitrile solution containing a few drops of water. A crystal was attached to a glass fiber and mounted on a Siemens SMART Platform CCD diffractometer for data collection at $100(1) \mathrm{K}^{\left[{ }^{[54]}\right.}$ The data collection was performed with Mo$K_{\alpha}$ radiation (graphite monochromator). The intensity data were corrected for absorption and decay (SADABS). ${ }^{[55]}$ The final cell constants were calculated from the $x y z$ centroids after integration (SAINT).$^{[56]}$ The structures were solved with SIR-97 ${ }^{[57]}$ and refined with SHELXL-97. ${ }^{[58]}$ The space group $P 2{ }_{1} 2{ }_{1} 2_{1}$ was determined on the basis of systematic absences and intensity statistics. A directmethods solution was calculated and provided most non-hydrogen atoms from the $E$-map. Full-matrix least-squares/difference Fourier cycles were performed, and the remaining non-hydrogen atoms were located. All non-hydrogen atoms were refined with anisotropic displacement parameters. All hydrogen atoms were placed in ideal positions and refined as riding atoms with relative isotropic displacement parameters. The structure was refined as an inversion twin (53:47). Please refer to Table 1 for additional crystal and refinement information. CCDC-676119 contains the supplementary crystallographic data for this paper. These data can be obtained free of charge from The Cambridge Crystallographic Data Centre via www.ccdc.cam.ac.uk/data_request/cif.

Physical Measurements: FTIR spectra were measured with a Varian 3100 Excalibur Series spectrometer. Optical spectra were recorded with a Cary $50 \mathrm{UV} / \mathrm{Vis}$ spectrophotometer. The NMR spectra were recorded at $25^{\circ} \mathrm{C}$ with a Bruker Avance II $400 \mathrm{MHz}$ instrument; the peaks of samples in [D]dichloromethane were referenced to tetramethylsilane (TMS), and the peaks of samples in $\mathrm{D}_{2} \mathrm{O}$ were referenced to trimethylsilyl propanoic acid sodium salt (TSP). The EPR spectra were recorded with samples in a suprasil quartz Dewar flask [cat. no WG-850(-Q), WILMAD Glass Co., Inc.] at $77 \mathrm{~K}$ and at $0.22 \mathrm{~mW}$ with a Varian Century Series ESR spectrometer operating at $9.28 \mathrm{GHz}$ with an E-4531 dual cavity, 9 in. magnet and a $200 \mathrm{~mW}$ klystron. For field calibration, Frémy's salt $[g=2.0056$, $\left.A^{\mathrm{N}}=13.09 \mathrm{G}\right]$ was employed. GC-MS experiments were performed with an HP 6890/5973 GC-MS instrument. The ESI-MS experiments were performed with a Thermo Finnigan TSQ Quantum Ultra AM triple quadrupole mass spectrometer. For the electrochemical measurements, a Pt electrode was used as the working electrode, and $\mathrm{Pt}$ wire and $\mathrm{Ag} / \mathrm{AgCl}$ were used as the auxiliary and reference electrodes, respectively. Cyclic voltammograms were obtained with a Bioanalytical Systems, Inc. potentiostat controlled by the Epsilon Electrochemical Workstation software. The measurements were externally referenced to ferrocene, and all electrochemical measurements were performed under dry nitrogen.

Reactivity Studies: The catalytic reactions were performed in a fume hood under continuous ambient light. To a $25 \mathrm{~mL}$ Schlenk flask was added $1(0.14 \mathrm{mmol})$. After the flask was purged with dry oxygen (Airgas, Industrial grade), TBAO (1.60 g, $2.80 \mathrm{mmol})$ dissolved in acetonitrile $(10 \mathrm{~mL})$ was added. The flask was stoppered to avoid evaporation. Aliquots (ca. $0.7 \mathrm{~mL}$ ) were periodically removed, placed in $5 \mathrm{~mL}$ vials, capped, and placed at $-70^{\circ} \mathrm{C}$ until analyzed. A solution containing only TBAO at the same concentra- 
tion as the reaction mixtures was run alongside the reactions, and aliquots were periodically removed and monitored in the same manner as the reaction.

\section{NMR Quantification of Oxalate}

Standard Preparation: [D]dichloromethane $(0.5 \mathrm{~mL})$ containing $2 \%$ w/w acetonitrile (internal standard) was added to oxalic acid $(5.0 \mathrm{mg})$ in a vial followed by $\mathrm{N}, \mathrm{O}$-bis(trimethylsilyl)trifluoroacetamide (BSTFA, 10 equiv.), and the solution was stirred for $0.5 \mathrm{~h}$ to ensure complete derivatization. The solution was quantitatively transferred to a preweighed NMR tube, and ${ }^{1} \mathrm{H}$ NMR spectroscopy was performed. The singlet peak at $\delta=0.36 \mathrm{ppm}$ corresponded to bis(trimethylsilyl) oxalate (DTMSO), ${ }^{[59]}$ and the integrated area for this peak was compared with that of the same peak in the sample.

Sample Preparation: To analyze the oxalate content, the reaction mixtures were thawed to ambient temperature in the dark, and $500 \mu \mathrm{L}$ was loaded on a cation exchange column $(12 \mathrm{~cm} \times 8 \mathrm{~mm}$, $\mathrm{Na}^{+}$form $)$and eluted with deionized water. To the eluant $(10 \mathrm{~g}$ collected) was added concentrated $\mathrm{HCl}$ ( 2.5 equiv.). The solvent was evaporated with a heated vacuum centrifuge. The obtained white solid was dissolved in [D]dichloromethane $(0.5 \mathrm{~mL})$ containing $2 \% \mathrm{w} / \mathrm{w}$ acetonitrile, and BSTFA $(200 \mu \mathrm{L} ; 15$ equiv. with respect to initial TBAO) was added. After stirring for $0.5 \mathrm{~h}$, the solution was filtered through a $0.45 \mu \mathrm{m}$ Nalgene syringe filter directly into a preweighed NMR tube. The complete transfer of the derivative to the NMR tube was ensured by washing the filter twice with the $[\mathrm{D}]$ dichloromethane solution $(1 \mathrm{~mL})$. The DTMSO was then identified and quantified by ${ }^{1} \mathrm{H}$ NMR spectroscopy.

$\mathrm{CO}_{2}$ Measurements: A homemade gas FTIR cell with $\mathrm{NaCl}$ windows was used (i.d. $37 \mathrm{~mm}$, path length: $100 \mathrm{~mm}$ ) to measure the $\mathrm{CO}_{2}$ in the headspace. The cell was evacuated to a pressure of 38 Torr and placed in the FTIR spectrophotometer chamber. The FTIR chamber was continuously purged with dry nitrogen to remove any moisture and traces of background $\mathrm{CO}_{2}$. The sample headspace was introduced into the cell, and the $\mathrm{CO}_{2}$ was identified by the peaks centered at $\tilde{v}=2350 \mathrm{~cm}^{-1}$. The integration of these peaks was performed in the range $\tilde{v}=2390-2280 \mathrm{~cm}^{-1}$, and the amount of $\mathrm{CO}_{2}$ was converted to mmol by using the ideal gas law.

\section{Acknowledgments}

The authors gratefully acknowledge Prof. M. D. Sevilla for assistance with EPR studies and Ms. Lijun Chen for assistance with ESI-MS experiments. Financial support from Oakland University (REF) and National Science Foundation (NSF) (grant CHE0748607 and award CHE-0821487) is gratefully acknowledged. P. L. P. and J. L. acknowledge graduate fellowships from Oakland University.

[1] V. R. Franceschi, P. A. Nakata, Ann. Rev. Plant Biol. 2005, 56, 41-71.

[2] M. Shimada, Y. Akamtsu, T. Tokimatsu, K. Mii, T. Hattori, J. Biotechnol. 1997, 53, 103-113.

[3] H. E. Williams, T. R. Wandzilak, J. Urol. 1989, 141, 742-747.

[4] J. M. Dunwell, A. Purvis, S. Khuri, Phytochemistry 2004, 65, $7-17$.

[5] M. R. Burrell, V. J. Just, L. Bowater, S. A. Fairhurst, L. Requena, D. M. Lawson, S. Bornemann, Biochemistry 2007, 46, $12327-12336$.

[6] E. J. Woo, J. M. Dunwell, P. W. Goodenough, A. C. Marvier, R. W. Pickersgill, Nat. Struct. Biol. 2000, 7, 1036-1040.
[7] O. Opaleye, S.-R. Rose, M. M. Whittaker, E.-J. Woo, J. W. Whittaker, R. W. Pickersgill, J. Biol. Chem. 2006, 281, 64286433.

[8] T. P. Begley, S. E. Ealick, Curr. Opin. Chem. Biol. 2004, 8, 508515.

[9] D. Svedruzic, S. Jonsson, C. G. Toyota, L. A. Reinhardt, S. Ricagno, Y. Lindqvist, N. G. J. Richards, Arch. Biochem. Biophys. 2005, 433, 176-192.

[10] C. H. Chang, N. G. J. Richards, J. Chem. Theory Comput. 2005, 1, 994-1007.

[11] T. Borowski, A. Bassan, N. G. J. Richards, P. E. M. Siegbahn, J. Chem. Theory Comput. 2005, 1, 686-693.

[12] E. W. Moomaw, E. Hoffer, P. Moussatche, J. C. Salerno, M. Grant, B. Immelman, R. Uberto, A. Ozarowski, A. Angerhofer, PLOS ONE 2013, 8, e57933.

[13] P. Moussatche, A. Angerhofer, W. Imaram, E. Hoffer, K. Uberto, C. Brooks, C. Bruce, D. Sledge, N. G. J. Richards, E. W. Moomaw, Arch. Biochem. Biophys. 2011, 509, 100-107.

[14] M. M. Whittaker, H.-Y. Pan, E. T. Yuk1, J. W. Whittaker, J. Biol. Chem. 2007, 282, 7011-7023.

[15] M. M. Makowska-Grzyska, E. Szajna, C. Shipley, A. M. Arif, M. H. Mitchell, J. A. Halfen, L. M. Berreau, Inorg. Chem. 2003, 42, 7472-7488.

[16] A. L. Fuller, R. E. Watkins, K. R. Dunbar, A. V. Prosvirin, A. M. Arif, L. M. Berreau, Dalton Trans. 2005, 1891-1896.

[17] M. Scarpellini, J. Grätjens, O. J. Martin, J. W. Kampf, S. E. Sherman, V. L. Pecoraro, Inorg. Chem. 2008, 47, 3584-3593.

[18] A. L. Fuller, R. E. Watkins, A. M. Arif, L. M. Berreau, Inorg. Chim. Acta 2006, 359, 1282-1290.

[19] A. Warden, B. Graham, M. T. W. Hearn, L. Spiccia, Org. Lett. 2001, 3, 2855-2858.

[20] A. C. Warden, L. Spiccia, M. T. W. Hearn, J. F. Boas, J. R. Pilbrow, Dalton Trans. 2005, 1804-1813.

[21] A. Y. S. Malkhasian, M. E. Finch, B. Nikolovski, A. Menon, B. E. Kucera, F. A. Chavez, Inorg. Chem. 2007, 46, 2950-2952.

[22] A. Y. S. Malkhasian, M. E. Finch, P. L. Pawlak, J. M. Anderson, W. W. Brennessel, F. A. Chavez, Z. Anorg. Allg. Chem. 2008, 634, 1087-1092.

[23] The low solubility of $\mathbf{1}$ did not allow us to obtain higher quality crystals.

[24] N. Arulsamy, J. Glerup, D. J. Hodgson, Inorg. Chem. 1994, 33, 3043-3050.

[25] A. Bencini, A. Bianchi, P. Dapporto, E. Garciaespana, V. Marcelino, M. Micheloni, P. Paoletti, P. Paoli, Inorg. Chem. 1990, 29, 1716-1718.

[26] C. Hureau, S. Groni, R. Guillot, G. Blondin, C. Duboc, E. Anxolabehere-Mallart, Inorg. Chem. 2008, 47, 11444-11444.

[27] J. Coyle, M. G. B. Drew, C. J. Harding, J. Nelson, R. M. Town, J. Chem. Soc., Dalton Trans. 1997, 1123-1125.

[28] I. I. Creaser, L. M. Engelhardt, J. M. Harrowfield, A. M. Sargeson, B. W. Skelton, A. H. White, Aust. J. Chem. 1993, 46, 465-476.

[29] A. Deroche, I. Morgenstern-Badarau, M. Cesario, J. Guilhem, B. Keita, L. Nadjo, C. Houée-Levin, J. Am. Chem. Soc. 1996, $118,4567-4573$.

[30] L. Valencia, P. Perez-Lourido, R. Bastida, A. Macias, J. Organomet. Chem. 2009, 694, 2185-2190.

[31] L. R. Gahan, V. A. Grillo, T. W. Hambley, G. R. Hanson, C. J. Hawkins, E. M. Proudfoot, B. Moubaraki, K. S. Murray, D. M. Wang, Inorg. Chem. 1996, 35, 1039-1044.

[32] K. Wieghardt, E. Schoffmann, B. Nuber, J. Weiss, Inorg. Chem. 1986, 25, 4877-4883.

[33] P. L. Pawlak, M. Panda, R. Loloee, B. E. Kucera, J. P. Costes, J. P. Tuchagues, F. A. Chavez, Dalton Trans. 2011, 40, 29262931.

[34] C. Mantel, C. Baffert, I. Romero, A. Deronzier, J. Pecaut, M. N. Collomb, C. Duboc, Inorg. Chem. 2004, 43, 6455-6463.

[35] M. M. Whittaker, J. W. Whittaker, J. Biol. Inorg. Chem. 2002, 7, 136-145. 
[36] R. A. Geiger, S. Chattopadhyay, V. W. Day, T. A. Jackson, J. Am. Chem. Soc. 2010, 132, 2821-2831.

[37] C. R. Goldsmith, A. P. Cole, T. D. P. Stack, J. Am. Chem. Soc. 2005, 127, 9904-9912.

[38] A. W. Adamson, W. L. Waltz, E. Zinato, D. W. Watts, P. D. Fleischauer, R. D. Lindholm, Chem. Rev. 1968, 68, 541-585.

[39] G. B. Porter, J. G. W. Doering, S. Karanka, J. Am. Chem. Soc. 1962, 84, 4027-4029.

[40] H. Cao, S. L. Suib, J. Am. Chem. Soc. 1994, 116, 5334-5342.

[41] H. Taube, J. Am. Chem. Soc. 1948, 70, 1216-1220.

[42] M. A. Suwyn, R. E. Hamm, Inorg. Chem. 1967, 6, 142-145.

[43] N. Ganapathisubramanian, J. Phys. Chem. 1988, 92, 414- 417.

[44] S. Mukhopadhyay, S. Chaudhuri, R. Das, R. Banerjee, Can. J. Chem. 1993, 71, 2155-2159.

[45] D. K. Banerjee, C. C. Budke, Anal. Chem. 1964, 36, 792-796.

[46] A. E. Albers, B. C. Dickinson, E. W. Miller, C. J. Chang, Bioorg. Med. Chem. Lett. 2008, 18, 5948-5950.

[47] A. Chaubey, B. D. Malhotra, Biosens. Bioelectron. 2002, 17, 441-456.

[48] D. F. Leto, T. A. Jackson, J. Biol. Inorg. Chem. 2014, 19, 1-15.

[49] M. K. Coggins, X. Sun, Y. Kwak, E. I. Solomon, E. V. RybakAkimova, J. A. Kovacs, J. Am. Chem. Soc. 2013, 135, 56315640 .
[50] E. R. Pérez，J. R. Garcia，D. R. Cardoso, B. R. McGarvey, E. A. Batista, U. P. Rodriguez-Filho, W. Vielstich, D. W. Franco, J. Electroanal. Chem. 2005, 578, 87-94.

[51] K. A. Hislop, J. R. Bolton, Environ. Sci. Technol. 1999, 33, 3119-3126.

[52] D. J. Poulton, H. W. Baldwin, Can. J. Chem. 1967, 45, 1045 1050.

[53] S. C. Cheng, C. A. Blaine, M. G. Hill, K. R. Mann, Inorg. Chem. 1996, 35, 7704-7708.

[54] APEX2, v. 2010.7-0, Bruker AXS, Madison, WI, 2010.

[55] R. Blessing, Acta Crystallogr., Sect. A 1995, 51, 33-38.

[56] SAINT, v. 7.68A, Bruker AXS, Madison, WI, 2009.

[57] A. Altomare, M. C. Burla, M. Camalli, G. Cascarano, C. Giacovazzo, A. Guarliardi, A. G. G. Moliterni, G. Polidori, R. Spagna, J. Appl. Crystallogr. 1999, 32, 115-119.

[58] G. M. Sheldrick, Acta Crystallogr., Sect. A 2008, 64, 112-122.

[59] W. Xu, C. A. Angell, Electrochem. Solid-State Lett. 2001, 4, E1-E4.

Received: September 3, 2014

Published Online: January 8, 2015 